Gut, 1972, 13, 880-886

\title{
The absorption and secretion of water and electrolytes across the healthy and the diseased human colonic mucosa measured in vitro
}

\author{
E. Q. ARCHAMPONG, J. HARRIS, AND C. G. CLARK \\ From the Department of Surgery, University College Hospital Medical School, London
}

SUMMARY An 'in-vitro' technique is described for measuring quantitatively the absorption and secretion of water and electrolytes, the short circuiting current, and the simultaneous bidirectional flux rates of ions across the healthy and diseased colonic mucosa. The results show that the normal colon absorbs both sodium and water and secretes potassium.

In both ulcerative colitis and Crohn's disease there is a reversal of sodium and water flux and potassium secretion is increased.

A measure of the simultaneous bidirectional flux rates under conditions of zero potential has allowed us to use the Ussing equation to analyse some of the factors involved in sodium transport across the healthy and diseased mucosa.

Measurement of the rates of absorption and secretion of water and electrolytes by the human colon have been made using the technique of colonic perfusion (Harris and Shields, 1970), and by absorption tests carried out at the time of colectomy (Duthie, Watts, de Dombal, and Goligher, 1964). We, like Grady, Duhamel, and Moore (1970), have modified the technique introduced by Ussing and Zerahn (1951), to measure the net transport and simultaneous bidirectional flux rates of water and electrolytes across the human colonic epithelium studied in vitro. This method allows a direct measure of electrolyte transfer to be made in relation to mucosal surface area. It also permits an assessment of the electrical activity generated across the mucosa, and enables an analysis of some of the factors which may influence it.

\section{Materials and Methods}

The apparatus (see Fig.) consists of two identical perspex chambers between which is mounted a flat sheet of colonic mucosa. The dependent part of each chamber incorporates a Y-shaped inlet adjacent to the mucosa. Through one limb of this connexion

Correspondence to: Professor C. G. Clark, Department of Surgery, University College Hospital Medical School, London, WC1E 6JJ.

Received for publication 5 September 1972. is carried an electrode comprising a long, narrow polyethylene tube filled with $4 \%$ agar saturated with potassium chloride. This electrode is placed close to the mucous membrane and leads to a potassium chloride bridge, from which a calomel electrode is

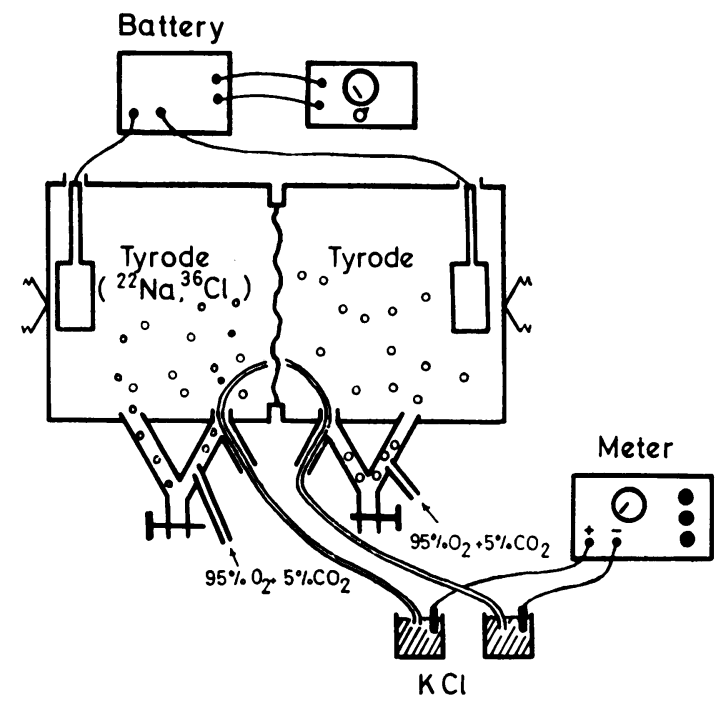

Figure Diagram of apparatus. 
connected to a millivoltmeter. The electrode adjacent to the surface epithelium is connected to the high 'input' terminal of the millivoltmeter. The other limb of the $Y$ connexion allows oxygen to be introduced into the chamber and provides a means for recirculating test solution within the system.

At the top of each chamber, and as far away as possible from the mucous membrane, is a wide-bore aperture $(1 \mathrm{~cm}$ diameter) which allows fresh test solution to be put into each chamber. The rubber bung sealing this aperture carries a needle to allow the escape of excess oxygen from the chamber, and also a lead which is connected to a highly polished silver plate $1 \mathrm{~cm}$ square. The other end of this lead is connected to an external battery and then in series to a microammeter. This additional device measures the short circuit current through the tissue during the experiment. The whole apparatus is sealed and mounted between two screw clamps, positioned at either end of the perspex chambers.

The test solution introduced into the chamber facing the mucosal side was modified Tyrode's solution (Code and McIntire, 1956) containing the radioactive isotopes of sodium $\left({ }^{22} \mathrm{Na}, 5 \mu \mathrm{c}\right.$ per litre), potassium $\left({ }^{42} \mathrm{~K}, 4 \mu \mathrm{c}\right.$ per litre), and chloride $\left({ }^{36} \mathrm{Cl} 100 \mu \mathrm{c}\right.$ per litre). Polyethylene glycol (PEG 4000, $1 \mathrm{~g} \mathrm{w} / \mathrm{v}$ ) was used as a volume indicator. Modified Tyrode's solution alone was put into the opposite chamber. Thus, save for the addition of isotopes and volume indicator, the solution on either side of the membrane was identical and maintained throughout at $37^{\circ} \mathrm{C}$ in an incubator.

At the beginning of each experiment the potential difference across the membrane was measured and then reduced to zero ('clamped down') using the short circuiting device. The test solution was left in the chamber for 30 minutes and the short circuiting current was recorded every three minutes throughout the experiment. Both chambers were then emptied through the stem of the $Y$ connexion and their contents analysed. Fresh test solution was then introduced and the experiment repeated. Generally the tissue retained its viability for at least two hours, thus enabling four experiments to be carried out.

Specimens of colonic mucosa were obtained from seven patients (five males, and two females) who underwent large bowel surgery for cancer. Their ages ranged from 45 to 75 years. Mucosal samples were also obtained from eight patients with inflammatory disease of the colon (four with diffuse protocolitis and four with Crohn's disease). In both groups the disease was of such extent and severity as to demand panproctocolectomy. In these patients the ages were between 23 and 47 years.

Immediately after colectomy segments of large intestine were pinned out on a board and the mucosa was carefully dissected from the underlying bowel wall musculature. After this, the membrane $2 \cdot 8 \mathrm{~cm}^{-2}$ was washed in modified Tyrode's solution and then carefully mounted between the two chambers. All specimens were obtained from the left side of the colon, those from the control (cancer) patients being taken at least $10 \mathrm{~cm}$ away from the edge of the tumour.

The concentrations of sodium and potassium in all specimens were measured in duplicate using a Technicon mark IV AutoAnalyzer. The chemical concentration of chloride was estimated using the mercuric nitrate method described by Schales and Schales (1941). The separate activities of sodium and potassium were estimated by counting the solution first in a well-type scintillation counter-this measured both ${ }^{22} \mathrm{Na}$ and ${ }^{42} \mathrm{~K}$. After seven to 10 days (when ${ }^{42} \mathrm{~K}$ had decayed) these specimens were recounted, and by difference the separate activities of these isotopes were measured. At the same time the concentration of ${ }^{36} \mathrm{Cl}$ was determined by means of a Geiger-Müller counter. The concentration of PEG 4000 was estimated using the turbidometric method of Hydén (1956).

\section{Calculations}

The rates of net transport were based on the formulae proposed by Visscher, Fetcher, Carr, Gregor, Bushey, and Barker (1944a) and by Visscher, Varco, Carr, Dean, and Erickson (1944b).

Rate of net transport of water $\left(\mathrm{ml} / \mathrm{cm}^{-2} / \mathrm{min}^{-1}\right)$

$$
=\left[\mathrm{V}_{1}-\frac{\left(\mathrm{V}_{1} \mathrm{C}_{\mathrm{PEG}_{1}}\right)}{\mathrm{C}_{\mathrm{PEG}_{2}}}\right] \times \frac{1}{\mathrm{~A} \times \mathrm{t}}
$$

where $V_{1}$ is the volume of test solution introduced into the chamber on the mucosal side, $\mathrm{C}_{\mathrm{PEG}_{1}}$ and $\mathrm{C}_{\mathrm{PEG}_{2}}$ are the concentrations of PEG 4000 (mg per $100 \mathrm{ml}$ ) at the beginning and end of the experiment respectively. $A$ is the mucosal surface area in $\mathrm{cm}^{-2}$ and $t$ is time in minutes.

Rate of net transport of electrolytes ( $\mu$-equiv/ $\mathrm{cm}^{-2} / \mathrm{min}^{-1}$ )

$$
=\left[\left(\mathrm{V}_{1} \mathrm{C}_{\mathrm{E}_{1}}\right)-\left(\mathrm{V}_{1} \mathrm{C}_{\mathrm{E}_{2}} \times \frac{\left.\mathrm{C}_{\mathrm{PEG}_{1}}\right)}{\mathrm{C}_{\mathrm{PEG}_{2}}}\right] \times \frac{1000}{\mathrm{~A} \times \mathrm{t}}\right.
$$

where $C_{E_{1}}$ and $C_{E_{2}}$ are the concentrations of electrolyte (m-equiv/l) at the beginning and end of the experiment respectively.

The rates of movement of electrolyte across the mucous membrane $\left(\mu\right.$-equiv $\left./ \mathrm{cm}^{-2} / \mathrm{min}^{-1}\right)$ in the direction mucosa to serosa $(\mathrm{m} \rightarrow \mathrm{S})$. 
$\mathrm{m} \rightarrow \mathrm{S}=$

$\left[\left(\mathrm{V}_{1} \mathrm{C}^{*} \mathrm{E}_{1}\right)-\left(\mathrm{V}_{1} \mathrm{C}^{*} \mathrm{E}_{2} \times \mathrm{C}_{\mathrm{PEG}_{1}} / \mathrm{C}_{\mathrm{PEG}_{2}}\right)\right] \times 1000$

$\frac{1}{2}\left(\frac{C^{*} E_{1}}{C_{E_{1}}}+\frac{C^{*} E_{2}}{C_{E_{2}}}\right) \times A \times t$

where $C^{*} E_{1}$ and $C^{*} E_{2}$ are the activities of electrolytes (counts per second per $\mathrm{ml}$ ) at the beginning and end of the experiment respectively.

The rate of electrolyte movement in the direction of serosa to mucosa $(S \rightarrow m)=$ rate of movement out of chamber - rate of net transport

To convert the current measured in micro-amperes into microequivalents we have used Faraday's law ( $\mathrm{W}=$ micro-equivalents).

$$
\mathrm{W}=\frac{\mathrm{I} \times \mathrm{t} \times \mathrm{E}}{\mathrm{F} \times 10^{6}}
$$

where $t$ is the time in seconds, $E$ is the equivalent weight of the element $(\mathrm{Na})$, and $\mathrm{F}$ is the Faraday constant, and $I$ is the current measured in amps.

\section{Results}

NORMAL COLON

The normal colon was found to absorb sodium, chloride, and water and to secrete potassium (Tables I and II). The mean rate of sodium absorption was
$0 \cdot 170 \mu$-equiv $/ \mathrm{min}^{-1} / \mathrm{cm}^{-2}$ resulting from a simultaneous bidirectional flux across the mucosa in which $0.350 \mu$-equiv $/ \mathrm{min}^{-1} / \mathrm{cm}^{-2}$ left the mucosal chamber and $0 \cdot 181 \mu$-equiv $/ \mathrm{min}^{-1} / \mathrm{cm}^{-2}$ the serosal chamber. There was consistency in the results of net sodium transport (range 0.146 - 0.094 $\mu$-equiv/ $\min ^{-1} / \mathrm{cm}^{-2}$ ), though the activity of the mucosa was reflected by fluxes in the individual patient was more variable. There was a highly significant correlation between net sodium transport and the current required to neutralize the potential difference generated by the colonic epithelial cells $(\mathrm{P}<0.001)$.

There was a net secretion of potassium in all subjects, mean $-0.018 \mu$-equiv $/ \mathrm{min}^{-1} / \mathrm{cm}^{-2}$. In the three subjects in whom flux rates were measured the flux rate into the chamber was greater than movement in the opposite direction $(0.137$ and 0.118 $\mu$-equiv $/ \mathrm{min}^{-1} / \mathrm{cm}^{-2}$, respectively). The results for chloride showed net absorption of $0.041 \mu$-equiv/ $\mathrm{min}^{-1} / \mathrm{cm}^{-2}$ and in the three patients where flux rates were obtained this was accounted for by movement of $0.181 \mu$-equiv $/ \mathrm{min}^{-1} / \mathrm{cm}^{-2}$ out of the chamber, and a flux of $0 \cdot 140 \mu$-equiv $/ \mathrm{min}^{-1} / \mathrm{cm}^{-2}$ into the chamber.

ULCERATIVE COLITIS AND CROHN'S DISEASE OF THE COLON

The results obtained from four patients with

\begin{tabular}{|c|c|c|c|c|c|}
\hline Patient & Net Na Transport & $\begin{array}{l}\text { Na Flux out of } \\
\text { Chamber }(\mu-\text { equiv/ } \\
\left.\min ^{-1} / \mathrm{cm}^{-2}\right)\end{array}$ & Na Flux into Chamber & $\begin{array}{l}\text { Short Circuit Current } \\
\left(\mu-e q u i v / \mathrm{min}^{-1} / \mathrm{cm}^{-2}\right)\end{array}$ & $\begin{array}{l}\text { Net Transport Water } \\
\left(\mathrm{ml}^{\prime} \mathrm{min}^{-1}\right)\end{array}$ \\
\hline $\begin{array}{l}1 \\
2 \\
3 \\
4 \\
5 \\
6 \\
7\end{array}$ & $\begin{array}{l}0.184 \\
0.194 \\
0 \cdot 155 \\
0 \cdot 146 \\
0.174 \\
0 \cdot 168 \\
0 \cdot 167\end{array}$ & $\begin{array}{l}0 \cdot 364 \\
0 \cdot 407 \\
0 \cdot 265 \\
0 \cdot 257 \\
0.406 \\
0 \cdot 357 \\
0 \cdot 396\end{array}$ & $\begin{array}{l}0.180 \\
0.213 \\
0.110 \\
0.111 \\
0.232 \\
0.189 \\
0.229\end{array}$ & $\begin{array}{l}0.135 \\
0.140 \\
0 \cdot 098 \\
0 \cdot 111 \\
0.117 \\
0.116 \\
0.096\end{array}$ & $\begin{array}{l}0.002 \\
0.002 \\
0.001 \\
0.001 \\
0.002 \\
0.001 \\
0.001\end{array}$ \\
\hline $\begin{array}{l}\text { Mean } \\
1 \mathrm{SD}\end{array}$ & $\begin{array}{l}0.170 \\
0.014\end{array}$ & $\begin{array}{l}0.350 \\
0.063\end{array}$ & $\begin{array}{l}0.181 \\
0.051\end{array}$ & $\begin{array}{l}0.116 \\
0.014\end{array}$ & $\begin{array}{l}0.001 \\
0.004\end{array}$ \\
\hline
\end{tabular}

Table I Rates of sodium and water transport and short circuit current across the colonic mucosa of control subjects measured in vitro

\begin{tabular}{|c|c|c|c|c|c|c|}
\hline Patient & Net $K$ Transport & $\begin{array}{l}\text { K Flux out of } \\
\text { Chamber } \\
(\mu-e q u i v / \\
\left.\min ^{-1} / \mathrm{cm}^{2}\right)\end{array}$ & $\begin{array}{l}\text { K Flux into } \\
\text { Chamber }\end{array}$ & Net Cl Transport & $\begin{array}{l}\text { Cl Flux out of } \\
\text { Chamber } \\
(\mu-e q u i v / \\
\left.\min ^{-1} / \mathrm{cm}^{-2}\right)\end{array}$ & $\begin{array}{l}\text { Cl Flux into } \\
\text { Chamber }\end{array}$ \\
\hline $\begin{array}{l}1 \\
2 \\
3 \\
4 \\
5 \\
6 \\
7\end{array}$ & $\begin{array}{l}-0.028 \\
-0.017 \\
-0.017 \\
-0.020 \\
-0.016 \\
-0.016 \\
-0.014\end{array}$ & $\begin{array}{l}0.109 \\
\overline{0.142} \\
- \\
\overline{0} \\
0.103\end{array}$ & $\begin{array}{l}0.137 \\
\overline{0.158} \\
= \\
\overline{-} \\
0.116\end{array}$ & $\begin{array}{l}0.038 \\
0.048 \\
0.046 \\
0.032 \\
0.044 \\
0.040 \\
0.038\end{array}$ & $\begin{array}{l}0.259 \\
\overline{0.143} \\
\overline{-} \\
\overline{0} \\
0.140\end{array}$ & $\begin{array}{l}0.221 \\
\overline{0.096} \\
- \\
\overline{-} \\
0.102\end{array}$ \\
\hline $\begin{array}{l}\text { Mean } \\
1 \text { SD }\end{array}$ & $\begin{array}{l}-0.018 \\
\pm 0.005\end{array}$ & $\underline{0.118}$ & $\frac{0 \cdot 137}{-}$ & $\begin{array}{r}0.041 \\
\pm 0.006\end{array}$ & $\begin{array}{l}0 \cdot 181 \\
-\end{array}$ & $\begin{array}{l}0 \cdot 140 \\
-\end{array}$ \\
\hline
\end{tabular}

Table II Rates of potassium and chloride transport across the colonic mucosa of control subjects measured in vitro 
ulcerative colitis differed markedly from those of normal subjects (Tables III and IV). There was secretion of sodium in every case with a mean of $-0.138 \mu$-equiv $/ \mathrm{min}^{-1} / \mathrm{cm}^{-2}$. The individual flux rates for sodium varied widely and in patients 8 and 9 were in excess of $1 \mathrm{~m}$-equiv $/ \mathrm{min}^{-1} / \mathrm{cm}^{-2}$ in each direction. The mean results for sodium fluxes of $0.725 \mu$-equiv $/ \mathrm{min}^{-1} / \mathrm{cm}^{-2}$ and $0.863 \mu$-equiv $/ \mathrm{min}^{-1} /$ $\mathrm{cm}^{-2}$, out of, and into the chamber, respectively, must therefore be interpreted with caution.

The results of sodium transport in the patients with Crohn's disease were similar to those with proctocolitis, and can be considered here. Again there was a net secretion of sodium with a mean of -0.427 $\mu$-equiv/min $-1 / \mathrm{cm}^{-2}$ but the mean results for flux rates are exaggerated by case 12 where $2.082 \mu$-equiv/ $\mathrm{min}^{-1} / \mathrm{cm}^{-2}$ left the mucosal chamber and 2.621 $\mu$-equiv $/ \mathrm{min}^{-1} / \mathrm{cm}^{-2}$ entered from the other side.
In both groups of patients the alteration of sodium transport was accompanied by a marked reduction in the electrical potential across the membrane. In five cases net sodium secretion was accompanied by net water secretion (Table III).

In patients with inflammatory bowel disease potassium flux rates were measured in only two patients in each group (Table IV). The net loss of potassium was greater than normal, particularly in patients with ulcerative colitis. Nevertheless potassium loss could be considered within normal limits in three of these patients (case 10, ulcerative colitis; cases 14 and 15 , Crohn's disease). It is unfortunate that ${ }^{12} \mathrm{~K}$ was not available to measure flux rates of potassium in the subject with the greatest losses. There was a net loss of chloride in every case, the loss being greater in patients with Crohn's disease.

\begin{tabular}{|c|c|c|c|c|c|}
\hline Patient & Net Na Transport & $\begin{array}{l}\text { Na Flux out of Chamber } \\
\left.\text { ( } \mu \text {-equiv/min }{ }^{-1} / \mathrm{cm}^{-2}\right)\end{array}$ & Na Flux into Chamber & $\begin{array}{l}\text { Short Circuit Current } \\
\left(\mu-e q u i v / \mathrm{min}^{-1} / \mathrm{cm}^{-2}\right)\end{array}$ & $\begin{array}{l}\text { Net Water Transport } \\
\left(\mathrm{ml}^{\prime} \mathrm{min}^{-1}\right)\end{array}$ \\
\hline $\begin{array}{l}\text { Ulcerative Coli } \\
8 \\
9 \\
10 \\
11\end{array}$ & $\begin{array}{l}\text { is } \\
-0.110 \\
-0.218 \\
-0.064 \\
-0.161\end{array}$ & $\begin{array}{l}1.302 \\
1.455 \\
0.087 \\
0.055\end{array}$ & $\begin{array}{l}1.411 \\
1.673 \\
0.151 \\
0.215\end{array}$ & $\begin{array}{l}0.008 \\
0.004 \\
0.016 \\
0.012\end{array}$ & $\begin{array}{c}0.0 \\
-0.002 \\
-0.001 \\
-0.001\end{array}$ \\
\hline Mean 1 SD & $\begin{array}{l}-0.138 \\
\pm 0.066\end{array}$ & $\begin{array}{r}0.725 \\
\pm 0.757\end{array}$ & $\begin{array}{r}0.863 \\
\pm 0.792\end{array}$ & $\begin{array}{l}0.010 \\
\pm 0.0\end{array}$ & $\begin{array}{l}-0.001 \\
\pm 0.0\end{array}$ \\
\hline $\begin{array}{l}\text { Crohn's Diseas } \\
12 \\
13 \\
14 \\
15\end{array}$ & $\begin{array}{l}-0.539 \\
-0.757 \\
-0.239 \\
-0.172\end{array}$ & $\begin{array}{l}2.082 \\
0.013 \\
0.241 \\
0.147\end{array}$ & $\begin{array}{l}2.621 \\
0.769 \\
0.480 \\
0.318\end{array}$ & $\begin{array}{l}0.003 \\
0.019 \\
0.011 \\
0.027\end{array}$ & $\begin{array}{c}-0.004 \\
-0.006 \\
0.0 \\
0.0\end{array}$ \\
\hline $\begin{array}{l}\text { Mean } \\
1 \text { SD }\end{array}$ & $\begin{array}{l}-0.427 \\
\pm 0.272\end{array}$ & $\begin{array}{r}0.621 \\
\pm 0.979\end{array}$ & $\begin{array}{r}1.047 \\
\pm 1.066\end{array}$ & $\begin{array}{r}0.015 \\
\pm 0.010\end{array}$ & $\begin{array}{l}-0.003 \\
\pm 0.003\end{array}$ \\
\hline
\end{tabular}

Table III Rates of sodium and water transport and the short circuit current across the diseased colonic mucosa measured in vitro

\begin{tabular}{|c|c|c|c|c|c|c|}
\hline Patient & Net $K$ Transport & 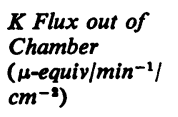 & $\begin{array}{l}\text { K Flux into } \\
\text { Chamber }\end{array}$ & Net $\mathrm{Cl}$ Transport & $\begin{array}{l}\text { Cl Flux out of } \\
\text { Chamber } \\
\left(\mu-e q u i v / \min ^{-1} /\right. \\
\left.\mathrm{cm}^{-2}\right)\end{array}$ & $\begin{array}{l}\text { Cl Flux into } \\
\text { Chamber }\end{array}$ \\
\hline \multicolumn{7}{|l|}{ Ulcerative Colitis } \\
\hline $\begin{array}{l}8 \\
9\end{array}$ & $\begin{array}{l}-0.068 \\
-0.534\end{array}$ & - & - & $z^{-0.165}$ & $\bar{z}$ & $\overline{-}$ \\
\hline 10 & $\begin{array}{l}-0.015 \\
-0.037\end{array}$ & $\begin{array}{l}0.128 \\
0.089\end{array}$ & $\begin{array}{l}0.144 \\
0.125\end{array}$ & $\begin{array}{l}-0.143 \\
-0.192\end{array}$ & $\begin{array}{l}0.083 \\
0.061\end{array}$ & $\begin{array}{l}0.226 \\
0.252\end{array}$ \\
\hline $\begin{array}{l}\text { Mean } \\
1 \text { SD }\end{array}$ & $\begin{array}{l}-0.164 \\
+0.248\end{array}$ & 0.109 & 0.135 & -0.167 & 0.072 & 0.239 \\
\hline \multicolumn{7}{|l|}{ Crohn's Disease } \\
\hline 12 & -0.105 & - & - & -0.230 & - & - \\
\hline 13 & -0.066 & - & - & -0.445 & $\overline{0}$ & \\
\hline $\begin{array}{l}14 \\
15\end{array}$ & $\begin{array}{l}-0.025 \\
-0.021\end{array}$ & $\begin{array}{l}0.125 \\
0.101\end{array}$ & $\begin{array}{l}0.150 \\
0.121\end{array}$ & $\begin{array}{l}-0.286 \\
-0.163\end{array}$ & $\begin{array}{l}0.075 \\
0.121\end{array}$ & $\begin{array}{l}0.362 \\
0.284\end{array}$ \\
\hline Mean & -0.054 & 0.113 & 0.136 & -0.281 & 0.098 & 0.323 \\
\hline $1 \mathrm{SD}$ & \pm 0.039 & - & - & \pm 0.120 & - & 一 \\
\hline
\end{tabular}

Table IV Rates of potassium and chloride transport across the diseased colonic mucosa measured in vitro 


\section{Discussion}

There have been several attempts to measure electrolyte transfer across the human colon (Welch, Adams, and Wakefield, 1936; 1937; Levitan, Fordtran, Burrows, and Ingelfinger, 1962; Duthie et al, 1964; Shields, 1966; Harris and Shields, 1970). This in-vitro method of study has many inherent advantages over those hitherto employed. Its principal asset is that it allows simple direct measurement of the transfer of water and electrolytes across the human colon which can be expressed accurately in relation to the mucosal surface area. It provides a measure of the simultaneous bidirectional flux rates across the epithelium and an assessment of the potential difference generated by the mucosa. In addition, a simultaneous analysis of the contents of both chambers has made possible a study of the principles involved in sodium transport by the human colonic mucosa both in health and disease. Its chief limitation is that at best only two hours' continuous observation can be made before significant deterioration of the tissue occurs, but this appears to be long enough to show differences between the normal and diseased colon.

At the beginning of these experiments certain precautions were necessary. In every case at the time of colectomy, the blood supply to the gut was divided as late as possible so that the interval between resection and mounting the tissue in the laboratory did not exceed 15 minutes. If the time interval was longer than half an hour, death of tissue occurred. Initially the effect of cooling was examined to see if this would allow a greater period of time between operative resection and the isolated chamber experiment, but this was unsuccessful. Immediately after colectomy dissection of the mucosa was carried out in oxygenated Tyrode's solution at $37^{\circ} \mathrm{C}$.

In all studies modified Tyrode's solution was used. This was because previous experiments on electrolyte transfer in health and disease have been carried out by one of us (J.H.) and it was clearly of interest to compare the results obtained by experiments in vivo and in vitro.

These in vitro studies confirm the in vivo results obtained by many other workers that the normal healthy colon absorbs sodium, chloride, and water, and secretes potassium into its lumen. These studies show that the colonic mucosa absorbs both sodium and water at a rate of $0.170 \mu$-equiv $/ \mathrm{min}^{-1} / \mathrm{cm}^{-2}$ and $0.0001 \mathrm{ml} / \mathrm{min}$ respectively. Although it is difficult to make a satisfactory comparison with the absolute flux rates obtained in colonic perfusion experiments (Harris and Shields, 1970) the results obtained in the present study show good agreement. If the colon is regarded, as suggested by Edmonds (1971), as a tube
$150 \mathrm{~cm}$ long and $4 \mathrm{~cm}$ diameter, these values, if extrapolated, result in net sodium and water absorption of $320 \mu$-equiv $/ \mathrm{min}$ and $1.8 \mathrm{ml} / \mathrm{min}$ respectively across the entire colon. This agrees almost exactly with the results from perfusion studies made by Harris and Shields (1970) that in healthy subjects net sodium transport was 391 $\mu$-equiv/min and water absorption $1.85 \mathrm{ml} / \mathrm{min}$.

Our results for net sodium transport and the short circuiting current across the normal healthy colon are twice those obtained by Grady et al (1970) who used a similar in-vitro technique. The reason for this discrepancy is not immediately apparent, but it may be that variation in the interval between division of the blood supply to the segment of bowel at operation and mounting the tissue in the chamber is partly responsible.

The close correlation between in-vitro and in-vivo studies was not evident when net potassium secretion was calculated. Harris and Shields (1970) found that net potassium secretion into the lumen of the gut was only $3 \cdot 1 \mu$-equiv/min but the results of the present experiments give a value of $33.9 \mu$-equiv/ min. It is possible that the augmented potassium loss in the in-vitro study is the resultant of two factors. Some potassium may be released as a result of tissue damage following dissection of the mucosa and this may also be accompanied by the progressive release of potassium from the cells as the tissue deteriorates during the period of study.

In normal healthy subjects the positive correlation between net sodium absorption and net water transport was preserved. In all cases when sodium was absorbed, water was absorbed; at no time was either sodium or water secretion noted. Since there was also a positive correlation between net sodium transport and the short circulating current the simultaneous bidirectional flux rates of this cation across the isolated epithelium were examined. It was found that the absorption of $0.170 \mu$-equiv/ $/ \mathrm{min}^{-1}$ / $\mathrm{cm}^{-2}$ of sodium was brought about as a result of $0.350 \mu$-equiv $/ \mathrm{min}^{-1} / \mathrm{cm}^{-2}$ leaving the luminal side of the membrane and $0.181 \mu$-equiv $/ \mathrm{min}^{-1} / \mathrm{cm}^{-2}$ moving in the opposite direction (Table I). Under the conditions of this study, ie, complete electrical neutrality and equivalent ionic activities on both sides of the membrane, the finding that net sodium transport approximates to the short circuiting current suggests that the forces responsible for this must reside in the membrane itself. This is further emphasized by an analysis of the bidirectional flux rates. Using Ussing's (1949) modification of the Nernst equation:

$$
\frac{M_{m}-s}{M_{s}-m}=\frac{a_{m}}{a_{s}} \times e \frac{z F E}{R T}
$$


in which $\mathbf{M}_{\mathbf{m}-\mathrm{s}}$ and $\mathbf{M}_{\mathbf{s}-\mathbf{m}}$ are the fluxes between solutions on the mucosal and serosal sides respectively, $a_{m}$ and $a_{s}$, the chemical activity of sodium on the mucosal and serosal side; $z, F, R, T$ have their usual thermodynamic significance, and $\mathrm{E}$ is the potential difference between the two solutions, then under the conditions of this experiment when $a_{m}=a_{s}$, and $\mathrm{E}$ is zero,

$$
\frac{\mathbf{M}_{\mathbf{m}-\mathbf{s}}}{\mathbf{M}_{\mathbf{s}-\mathbf{m}}}=1 .
$$

Since this ratio in the experiments was greater than unity $(1 \cdot 6)$, this must indicate that in this study the movement of sodium is under forces similar to active transport. Since there is still net water transfer across the membrane the possible effect of solvent drag cannot be entirely ruled out. We, like Grady et al (1970), find a persistent discrepancy between net sodium transport and the short circuiting current. This must indicate that other factors are involved in generating the electrical potential. Whether this is due to a concomitant movement of another cation in the opposite direction or to a negatively charged ion in the same direction cannot be resolved from this study.

Unlike Devroede and Phillips (1969), who showed that chloride absorption was greater than sodium absorption from the normal colon, we find it to be less. This we consider is probably an artefact, for in this study we have repeatedly 'short circuited' the membrane, and it is possible that this has interfered with net chloride transport.

\section{ULCERATIVE COLITIS}

The in-vitro experiments showed a diminished absorption of sodium and water and an increased secretion of potassium, confirming the observations of Harris and Shields (1970). They found overall secretion of sodium and water in just under $50 \%$ of cases whereas the in-vitro studies demonstrate secretion in all cases. This discrepancy may be accounted for by the apparent greater severity of the disease in the patients in the present study, all of whom required panproctocolectomy and ileostomy. The alteration of net sodium transport was due to an increased flux of sodium into the luminal chamber of the system and was accompanied by a diminished short circuit current. The linear correlation between net sodium transport and net water absorption was preserved $(P>0.001)$.

Excessive losses of potassium were found in ulcerative colitis, though these were much greater than those found by Harris and Shields (1970). Lockwood, Harris, and Clark (1971) have recently shown that the mucosal cells in ulcerative colitis are $2^{*}$ abnormal and 'leak' potassium. The degree of this potassium loss is related to the severity of the disease, and there is recovery under the influence of drugs such as salazopyrin. The loss of potassium was particularly marked in cases 8 and 9 , where very great flux rates were also noted in the corresponding sodium fluxes. It was not possible to measure potassium flux in these two patients but the results may well reflect the severity of the disease.

\section{CROHN'S DISEASE}

Severe electrolyte losses are not well documented in cases of Crohn's disease of the large intestine. One possible explanation for this may be that Crohn's disease often has a patchy distribution and the relativity normal areas between diseased areas can compensate for many electrolyte changes. But where this disease is of such extent and severity as to demand panproctolectomy and ileostomy, as in the four cases studied, the losses of sodium, potassium, and water were equal to or even exceeded those found in ulcerative colitis. The reversal of sodium transport is accompanied by water secretion, and a reduced short circuiting current. An increased flux of sodium ions into the chamber was again responsible for the change in net sodium transport (Table III).

The results of these in-vitro studies in Crohn's disease for sodium and water transport are similar to those obtained by Head, Heaton, and Kinel (1969) using an in-vivo perfusion technique, but in addition we do find that there are excessive losses of potassium in this disease. However, it is difficult to compare the results of these two sets of experiments, as the test solution in their series was isotonic saline, and in ours modified Tyrode's solution; and the difference in the result may be due to variation in the chemical concentration gradient across the mucosa.

This method of study comparing the normal and diseased colon shows that in diffuse proctocolitis and Crohn's disease there is an altered pattern in the handling of water and electrolytes, resulting in the large intestine becoming less absorptive and more secretory in function. The results obtained parallel those observed using the technique of colonic perfusion-suggesting that this in-vitro method reflects the ionic exchanges across the large intestine. Such an experimental model would seem suited to analyse the effects of drugs and also chemical agents on the exchange of water and electrolytes across the healthy and diseased human colon.

We should like to thank Mr Peter Luther, Chief Technician in the Surgical Unit, for his assistance, and $\mathrm{Mr} \mathrm{R}$. C. Donmall, a medical student at University College Hospital, for his help in preparing a computer program. 


\section{References}

Code, C. F., and McIntire, F. C. (1956). Quantitative determination of histamine. Meth. biochem. Anal., 3, 49-95.

Devroede, G. J., and Phillips, S. F. (1969). Conservation of sodium, chloride, and water by the human colon. Gastroenterology, 56, 101-109.

Duthie, H. L., Watts, J. M., de Dombal, F. T., and Goligher, J. C. (1964). Serum electrolytes and colonic transfer of water and electrolytes in chronic ulcerative colitis. Gastroenterology, 47, 525-530.

Edmonds, C. J. (1971). Absorption of sodium and water by human rectum measured by a dialysis method. Gut, 12, 356-362.

Grady, G. F., Duhamel, R. C., and Moore, E. W. (1970). Active transport of sodium by human colon 'in vitro'. Gastroenterology, $59,583-588$.

Harris, J., and Shields, R. (1970). Absorption and secretion of water and electrolytes by the intact human colon in diffuse untreated proctocolitis. Gut, 11, 27-33.

Head, L. H., Heaton, J. W., Jr., and Kivel, R. M. (1969). Absorption of water and electrolytes in Crohn's disease of the colon. Gastroenterology, 56, 571-579.

Hydén, S. (1956). A turbidimetric method for the determination of higher polyethylene glycols in biological materials. $K$. LandtbrHögsk. Annlr., 22, 139-145.
Levitan, R., Fordtran, J. S., Burrows, B. A., and Ingelfinger, F. J. (1962). Water and salt absorption in the human colon. J. clin. Invest., 41, 1754-1759.

Lockwood, C. M., Harris, J., and Clark, C. G. (1971). Intracellular potassium in diffuse proctocolitis. Lancet, 1, 889-891.

Schales, O., and Schales, S. S. (1941). A simple and accurate method for the determination of chloride in biological fluids. J. biol. Chem., 140, 879-884.

Shields, R. (1966). Absorption and secretion of electrolytes and water by the human colon, with particular reference to benign adenoma and papilloma. Brit. J. Surg., 53, 893-897.

Ussing, H. H., and Zerahn, K. (1951). Active transport of sodium as the source of electric current in the short-circuited isolated frog skin. Acta physiol. scand., 23, 110-127.

Visscher, M. B., Fetcher, E. S., Jr., Carr, C. W., Gregor, H. P., Bushey, M. S., and Barker, D. E. (1944a). Isotope tracer studies on the movement of water and ions between intestinal lumen and blood. Amer. J. Physiol., 142, 550-575.

Visscher, M. B., Varco, R. H., Carr, C. W., Dean, R. B., and Erickson, D. (1944b). Sodium ion movement between the intestinal lumen and the blood. Amer. J. Physiol., 141, 488-505.

Welch, C. S., Adams, M., and Wakefield, E. G. (1937). Metabolic studies on chronic ulcerative colitis. J. clin. Invest., 16, 161168. 